\title{
Creating an Effective Form of Communication Strategy in Foreign Language Learning
}

\author{
Oksana V. Shemshurenko ${ }^{1, *}$, Liliya R. Nizamieva ${ }^{1}$, Gulnara I. Nazarova ${ }^{1}$, Gérard Broussois ${ }^{2}$ \\ ${ }^{1}$ Kazan Federal University, Russia \\ ${ }^{2}$ Ministry of National Education, Higher Education and Research, Russia
}

Received July 12, 2019; Revised September 20, 2019; Accepted September 27, 2019

Copyright $\subseteq 2019$ by authors, all rights reserved. Authors agree that this article remains permanently open access under the terms of the Creative Commons Attribution License 4.0 International License

\begin{abstract}
The present article is devoted to creating an effective form of communication strategy within the process of teaching a foreign language (FL) and providing a means of stimulating cognitive interest, motivation, as well as cognitive-practical independence among students in the process of mastering an FL. On the basis of the given analysis, it is concluded that communicative learning strategies can develop critical thinking in students by reason of the problematic nature of educational tasks and consequently create a basis for their linguistic self-organization and creativity. Thus, effective communication can meet established trends in modern education in order to strengthen the practical component of learning process for a more effective form of professional and professional-applied competencies of future graduates of higher education institutions. Within the framework of FL teaching, it also allows students to develop abilities to adapt to different linguistic situations, both domestic and professional, and have great prospects for their applications in the field of education due to their focus on further creative development and self-education in students.
\end{abstract}

Keywords Communicative Approach, Deductive Approach, Content of Education, Teaching a Foreign Language, Cognitive-Speech Independence, Competence, Transfer

\section{Introduction}

At present, communicative teaching methods are increasingly becoming important in the practice of teaching a foreign language (FL) in higher education institutions, ensuring the formation of professional and professional-applied competencies of future graduates. The contrast between deductive and communicative approaches in FL teaching can be thus assumed as a significant methodological aspect of content of education. For a long time, preference has been given to deductive teaching methods in this area, in which students could primarily receive theoretical information about certain specific aspects of a language in the form of rules and recommendations, and only then applied them in direct language practices. With regard to communicative FL teaching, theoretical knowledge is based on linguistic experience accompanied by more emphasis on active use of language rather than simply providing information about it [Mourlhon-Dallies, 2006].

\section{Methods}

Communicative approaches in pedagogy have a long history, traced back to Aristotle whose method, in comparison with Plato's, was based on acquisition of new knowledge on the basis of empirical experience through analyzing and establishing links between original data and building, consequently, logical structures that could appear in individual phenomena. These logical structures could also take the form of laws or behaviors.

From the point of view of the psychology of learning, it is well-known that no new knowledge can be built if it is not connected with previous one. In addition, gradual departure from pedagogical coercion, expressed in deductive methods, is towards a freer approach that takes students' needs and interests into account [Puzanov, 2016]. The communicative approach is also supported by the fact that the teaching process cannot be limited to mere transfer of knowledge, especially in FL teaching in professional fields. On the other hand, providing the formation of professional competencies in students to the will of the case is unacceptable, believing that they will discover what needs to be studied [Yarkova \& Khamitova, 2013].

Besides, explicit learning is considered as a specific type of learning to acquire new skills or to hone existing ones. It 
relies on clear instructions or rules that students attempt to implement during a practice session. To achieve explicit learning, students can make use of declarative knowledge (i.e. knowledge of facts, rules, and concepts) along with working memory (that is, the part of short-term memory concerned with immediate perceptual processing) to engage in a task [Champagne-Poirier, 2016]. Furthermore, it is based on the actualization of previous knowledge before the study of new educational materials. In the domain of pedagogy, this process has been called assimilation.

If new information does not fit into existing structures, it leads to imbalance as well as onset of a process labeled accommodation. It means, changing structures once they no longer allow for full assimilation of new information, which is regarded as the basis of an educational process according to the concept of explicit learning. The role of a teacher is thus to ensure transition to assimilation and to enhance previous knowledge [Dejean et al., 2011; [Ghazanfarpour et al., 2013]. This allows students to understand and relate their experience and what they are preparing to study. Thus, in order to ensure the effectiveness of further transfer in the introductory phase of explicit learning, the teacher helps to establish existing links between this knowledge and specific objectives of new training.

Transfer has been also described by Presseau as the process by which knowledge, gained in one context, is used in a new context either to build new knowledge or to develop new competencies or to perform new tasks. Such a transfer involves a number of cognitive operations. It should be noted that, for information to be integrated with memory, it must be sufficiently similar to existing structures because they serve as basic categories. Therefore, the transfer can be carried out only if these categories are activated during the execution of a new task, according to the established similarity between the original and the directly performed tasks [Presseau, 2000]. Within this cognitive process, the similarity between the previous and the present tasks helps students to select and mobilize the existing knowledge to find a solution in a new situation. That is why it is necessary to help students at the initial stage to understand contextual elements that can define a new situation or learning a new task. Once the task is accomplished, it is important that students become able to identify what is independent of the context; in other words, permanent components that do not change from one context to another.

\section{Results and Discussion}

Communicative approach can develop cognitive abilities in students, who can become an active participant in the process of their own learning. With regard to FL, communicative pedagogy suggests starting with exercises or, more broadly, with practical activities in a controlled educational process in order to further theorize experience or conceptual objectification of knowledge built on this basis. In other words, transition is not from theory to practice, but rather from practice to theory.

The given approach is based on active thinking processes and linguistic creativity, followed by removing the general from the particular, i.e. rules from specific examples, when students create their own linguistic space and integrate information, extracted through such an analysis, into the structure of their own personality. This means that the given information is passed "through oneself" and becomes the property of linguistic personality in the form of extracted knowledge, which creates one's linguistic reality brick by brick. It is also actively constructed by the cognizing subject since knowledge is not acquired in a passive manner [Poberezhny, 2010]. The information integrated in this way can be utilized at any time to solve new linguistic or speech problems. It should be noted that self-acquired knowledge is stored in memory longer than that presented by teachers in the finished form; and on the other hand, students may restore it on their own even if it is forgotten or lost over time.

Therefore, the use of communicative approach in the process of FL teaching was analyzed in this article. At the same time, the educational process went through three main phases:

1. Contextualization; when a teacher proceeds from specific examples or provisions to bring to the study topic, which under their guidance, students will have to try to identify. In case of possible difficulties, assistance from the teacher is not excluded.

2. Decontextualization or conceptualization; that aims to allow students to draw a general conclusion or position, based on the analysis of specific situations.

3. Recontextualization; during which students have to apply the identified provisions in another situation (this phase is usually used to assess the training potential of the lesson).

Therefore, it can be stated that communicative approach is an active one, through which students can take the fullest part in the learning process. They are thus invited to formulate ideas and determine the accuracy of the results via discussing them with the audience and the teacher [Carneiro et al., 2011; Villalobos, 2018]. In this regard, teachers should create learning situations that ensure active participation of students for conscious development of their knowledge as well as formation of necessary competencies [Fahrutdinova et al., 2016; Wyrasti et al., 2019].

However, this approach is not without its own drawbacks. One of them is wrong or incomplete understanding of the essence of a linguistic phenomenon. In this case; the regulatory activity of the teacher comes to the fore, who should, if necessary, direct analyses and discussions in classrooms and prevent possible mistakes by students. Other disadvantages are high costs of training as 
well as additional burdens on teachers in terms of preparation and planning of classes. Therefore, the choice in favor of deductive or communicative approaches for a particular stage of training will be carried out by teachers on the basis of training goals and objectives, analysis of a specific audience's needs, students' language base and their usual learning styles, as well as availability of necessary materials and resources for the educational process.

In the study of an FL on the basis of a communicative approach, preference should be thus given to authentic sources that allow to bring the learning process of language development closer to a natural one and provide a variety of studied linguistic materials for successful training in the transfer of the knowledge, extracted by students, in new speech situations, for the development of their speech skills and professional competencies [Carette et al., 2012; Andrianova et al., 2017]. The communicative approach can be accordingly applied both at the initial and advanced stages of training, in the transition of students from copying to reproduction and creativity, and then to the constructive and creative level of independence [Harvey, 2012; Sadykova \& Shelestova, 2016].

In order to prove the formation of the mechanism of knowledge transfer and competencies in the mastery of an FL, it is necessary to trace the strategies for solving similar communicative tasks, used by students in other contexts [Klimchak et al., 2016]. Students can be also asked to define their own transfer conditions, which will allow them to anticipate similar situations, in which they will be able to re-use their knowledge and competencies. A teacher should also encourage such a transfer by helping students to establish links and correspondences between the initial and new situations, to find permanent components of the communication strategy and to select among the previously acquired knowledge and competencies that they should use in solving new educational tasks.

\section{Summary}

Communicative approach promotes formation of activity and independence in individuals. It can also develop students' abilities to transmit and receive information and to successfully find a way out of difficult or unusual situations of communication [Kuzmina et al., 2018]. In this case, students themselves determine the ways as well as the means of mastering new approaches. However, the role of a teacher in this case is not passive, but they need the ability to show possible ways to achieve goals, to direct students' attempts for a more effective solution of the challenges, and, if necessary, to adjust conclusions formulated by students. The personal interest and involvement of both sides is also of great importance since they can remove contradictions in oppositions to deductive and communicative approaches and thus ensure their complementarity.

Using a communicative approach in an FL lesson, teachers must create conditions for personal growth of students in the area of their immediate development and provide them with the opportunity to successfully fulfill desired goals and objectives, taking into account the principles of affordability and accessibility. In case of difficulties or errors that are unavoidable in the learning process; teachers should direct students, correct their learning activities, and also help them to understand the cause of the error and develop ways to solve the problem, thus contributing to their real and constant development.

\section{Conclusions}

Thus, the use of communication strategies of linguistic self-realization in FL can meet the existing challenges of strengthening the practical orientation of modern education. In this case, not only the result but also the process by itself becomes of utmost importance, i.e. the ways and the means of achieving it once students realize the value of their learning activities for their future professional development. With regard to its individual orientation and correlation with personal experience and motivation in an individual; communicative approaches can have, therefore, great prospects of applications in the field of education, as they are aimed at further creative development and self-education in students.

\section{Acknowledgements}

This work was performed according to the Russian Government Program of Competitive Growth of Kazan Federal University.

\section{REFERENCES}

[1] Andrianova, N. S., Nizamieva, L. R., Nazarova, G. I., Ostroumova, O. F., Leblanc, C. (2017). The development of students' cognitive self-study while teaching reading in Fl Learning. Journal of History Culture and Art Research, 6(5), 321-326.

[2] Carette, E., Carton, F., Vlad, M. (2012). Diversités culturelles et enseignement du français dans le monde // Paris: PUG. 263 p.

[3] Carneiro, R., Lefrere, P., Steffens, K., Underwood, J. (2011). Self-Regulated Learning in Technology Enhanced Learning Environments. Rotterdam: Sense Publishers. 31 p.

[4] Champagne-Poirier, O. (2016). Les données autoethnographiques comme base à une théorisation des pratiques pédagogiques dans l'enseignement des approches Communications. Approches Communications en pédagogie, 3(2), 12-40. 
[5] Dejean, C., Mangenot, F., Soubrié, T. (2011). Apprentissages formels et informels, autonomie et guidage. Actes du colloque EPAL 2011, Université Stendhal. Grenoble, 3, 9-15.

[6] Fahrutdinova, R. A., Fahrutdinov R. R., Yusupov, R. N. (2016). The Model of forming Communication competence of students in the process of teaching the English language. International Journal of Environmental \& Science Education, 11(6), 1285-1294.

[7] Ghazanfarpour, H., Pourkhosravani, M., \& Mousavi, S. E. (2013). Geomorphic systems affecting the Kerman, UCT Journal of Social Sciences and Humanities Research, 1(1): 6-11.

[8] Harvey, B., Harvey, J. (2012). Creative Teaching Approaches in the Lifelong Learning Sector. Open University Press, $356 \mathrm{p}$.

[9] Klimchak, O. V., Galeyeva, G. I., Kulikovskaya, A. N. (2016). Association experiment in studying temporal vocabulary of the Spanish language. Journal of Language and Literature, 7(2), 245-248.

[10] Kuzmina, E. K., Nazarova, G. I., Nizamieva, L. R., Leblanc, C. (2018). Innovative technologies of teaching business French. International Journal of Engineering and Technology (UAE), 7(4). 85-87.

[11] Mourlhon-Dallies, F. (2006). Apprentissage du français en contexte professionnel: état de la recherche. Apprendre le français dans un contexte professionnel, Actes de rencontres de la Délégation Générale de la Langue Française. Paris, 28-33.

[12] Poberezhny, L. (2010). Constructivism in the theory and practice of education. Economics of education, 4, 16-18.

[13] Presseau, A. (2000). Efficacité de l'analyse d'interventions sur le transfert des apprentissages en mathématiques. Revue des sciences de l'éducation, 26(3), 515-544.

[14] Puzanov, A. P. (2016). Communication and deductive approaches in foreign language teaching. Herald of PFUR, series Pedagogy and psychology, 3, 89-98.

[15] Sadykova, A. G., Shelestova, O. V. (2016). Creativity development: The role of foreign language learning. International Journal of Environmental and Science Education, 11(15), 8163-8181.

[16] Villalobos, J. V. (2018). Politics as a requirement. On the concept of Human Rights and the right to an autobiography as an ethical category. Opción, 34(85-2), 9-19.

[17] Wyrasti, A. F., Sa'dijah, C., As'ari, A. R., \& Sulandra, I. M. (2019). The Misanalogical Construction of Undergraduate Students in Solving Cognitive Conflict Identification Task. International Electronic Journal of Mathematics Education, 14(1), 33-47. https://doi.org/10.12973/iejme/3961

[18] Yarkova, G. A., Khamitova, M. A. (2013). On the problem of formation of competencies as the basis of training for professional activity. Modern problems of science and education, 3, URL: http://science-education.ru/ru/article/vi ew $\mathrm{id}=9189$ (date accessed: 29.05 .2019 ). 